\title{
O Poder e Seu Controle
}

\author{
Manoel Gonçalves Ferreira Fitho \\ Professor Titular de Direito Constitucional \\ da Faculdade de Direito da USP
}

S U M $\triangle$ I I O

1. O fenômeno «poder».

2. Que é o poder?

3. Poder físico e poder moral.

A. O poder nas relações interindividuais.
4. O poder entre homens.
5. A fonte do poder: a superioridade.
6. A fonte da sujeição: a crença.
7. Modalidades de poder.
8. O poder nos grupos.

B. O poder nas relações entre grupos.

9. $O$ poder dos grupos.

10. A superioridade.

11. A sujeição.

12. O poder $\theta$ as crencas.

13. Legitimidade e «consensus».

C. O poder na sociedade global.
14. A institucionalização do poder.
15. O poder politico.
16. O Estado.
17. Poder estatal e Direito.

D. O poder estatal na sociedade contemporânea.
18. O poder «legal».
19. A «classe» polftica.
20. Classe política $\theta$ elite económica.
21. Poder polftico e poder militar.
22. Poder politico e poder espiritual.
23. A disputa pelo poder.
24. Poder estatal limitado e pođer estatal totalitário.

E. O controle do poder.

25. Poder e abuso do poder.

26. O controle do poder.

27. Controle do poder $\Theta$ Constituição.

28. Direito e controle do poder e pelo poder. 


\section{O fenômeno «poder».}

O homem depara a todo momento com o fenômeno poder. Tanto porque o exerce quanto porque o sofre. Não é de estranhar, por isso, que as ciências humanas, todas, se vejam às voltas, freqüentemente, com esse fenômeno onipresente. Assim é com a Ciência Política, com a Sociologia Política e, também, com o Direito Político.

O poder, contudo, é fenômeno fugídio, por muitas as suas faces. E numerosas as suas formas, espécies, tipos ... Disto resulta, como preliminar de estudos, a necessidade de clarificar conceitos, precisar caracteres, que sente vez por outra o especialista em qualquer das ciências humanas. Mormente se o seu campo de interesse é o político.

Com efeito, as ciências políticas se preocupam a tal ponto com o poder e suas manifestações que não raro são consideradas ciências «do poder». E no uso corrente, o qualificativo «político», que etimologicamente significa relativo à polis, ao estado, aos negócios públicos, se emprega como «concernente ao poder» (1).

Todavia, ora essas ciências encaram o Poder, ora analisam o poder, ou poderes. O Direito, por exemplo, inclui o Poder entre os elementos básicos do Estado, na lição clássica (2). E como o mais importante destes, pois é a causa formal do Estado. Tal Poder é a cabeça que dirige o povo, num determinado território, para a consecução do bem comum.

Mas, segundo registra a Ciência Política, esse Poder, elemento do Estado, é um entre muitos poderes que coexistem (e competem) na sociedade. E que ele é exercido (ou detido, ou gerado, pois não vale a pena entrar, aqui, na polêmica doutrinária) por algum ou alguns desses poderes sociais ${ }^{(3)}$.

E a Sociologia, na sua análise, descobre que o poder, ou os poderes, sobre que se debruça a Ciência Política, se decompõe em inúmeras relações interindividuais, uns tendo poder sobre outros, uns sofrendo o poder de outros. E que todos os homens, por viverem em sociedade, são, numa medida variável, sujeitos, ativos e passivos, do poder ${ }^{(4)}$.

\section{Que é o poder?}

A vista d'olhos que se acabou de perpassar justifica à sociedade o estudo que vem adiante. Quem negará que, com toda a razão e com muita necessidade, o estudioso de Direito do Estado se há de perguntar em que consiste o fenômeno poder? E quem o condenará por, em busca de resposta, ir além das lindes do Direito?

1. E posição de Maurice Duverger. Para este, a Ciência Política é a Ciência do Poder (Cf. Méthodes de la Science Politique, Paris: P.U.F., 1959, pág. 13).

2. Cf. Georg Jellinek, Teorfa General del Estado, trad. esp., B. Alres: Albatros, 1943, pág. 348 e segs.

3. V. Georges Burdeau, Traité de Science Politique, Paris: Lib. Générale, 1949, vol. I, no 177 .

4. Cf. sobre todo este tema, Jean Baechler, Lo Pouvoir Pur, Paris: Calmann-Levy, 1978. 
Num sentido amplo, poder é capacidade de alterar o mundo exterior. $\bar{E}$ capacidade de produzir efeitos externos, seja sobre coisas, seja sobre homens, que tem, num dado instante e lugar, um ser humano determinado, ou um grupo de pessoas. Dizer capacidade é admitir o poder como potencial. Entretanto, obviamente ele se evola, quando, ao procurar traduzir-se em ato, não logra efeito. Poder que não pode alcançar efeito não é poder, inexiste. Em outras palavras, o poder potencial existe se e enquanto se pode efetivar no mundo exterior, se e enquanto se pode tornar poder efetivo.

Cumpre observar, porém, que, em relação a «corpus», i.e., em relação a objetos físicos, o poder que não consegue efetivar-se no real, era apenas poder suposto e de fato inexistia. Em relação a homens, i.ê., sobre mentes, o poder suposto de um, ou alguns homens, obtém freqüentemente efeitos, porque o mais das vezes a suposição basta para ditar a conduta de quem sofre o poder. Este não «paga para ver» se realmente tal poder existe. Assim poder moral suposto é poder existente.

\section{Poder físico e poder «moral».}

Por alcançar resultados concretos e visíveis, o tipo mais definido de poder é o físico. Este é o poder sobre a natureza em geral. Consiste em obter modificações no quadro físico, naturalmente estabelecido. Atua sobre a natureza, aplicando as leis desta e, portanto, sendo condicionado por esta.

O poder físico aparece confundido com a força, porque seu exercício importa sempre num dispêndio de energia, (no uso da força, pois), ainda que a intensidade da força usada possa ser mínima.

Este poder físico pode ser exercido por homem sobre outro ou outros homens. Com o emprego da força, de uma força superior, um homem pode obrigar outro homem a fazer ou a sofrer o que não faria ou suportaria de modo próprio. O mais forte, destarte, exerce poder sobre o mais fraco, com o emprego de sua força que é maior. Com o emprego, sublinhe-se redundantemente, efetivo de uma força maior.

Quando não há emprego efetivo de força, ainda quando haja ameaça do uso desta, já não cabe falar de poder físico. Com efeito, a ameaça pode levar, como não raro leva, um homem a fazer o que o outro determina. Entretanto, é sua vontade, coagida embora, que comanda a execução da vontade alheia. O poder, neste caso limite, se exerce de mente a mente, é um poder «mental» ou «moral», que na hipótese se arrima de muito perto na força ${ }^{(5)}$. Mas pode ter outro fundamento que o temor da força alheia.

5. A expressão «poder moral» é aqui empregada sem qualquer conotação valorativa. O qualificativo «moral»é usado como o oposto de «físico». 
No poder moral, uma vontade se impõe a outra, apoiada numa «superioridade» que esta reconhece e aceita. Superioridade real ou suposta.

\section{A. O poder nas relações interindividuais \\ 4. 0 poder entre homens.}

Tanto o poder físico quanto o poder moral estão presentes nas relações interindividuais. Aqquele, porém, é bem menos freqüente do que este e tende a ser meio deste. Com efeito, a compulsão física que efetiva o poder físico é relativamente rara nas relações entre seres humanos, conquanto a ameaça de coação seja bem mais comum. $\mathrm{E}$ essa compulsão costuma ser instrumento para lograr resultado que, antes, se pretendeu como efeito de poder moral. E se pode supor que de mais em mais será dispensado o recurso à coação, mesmo para execução dos ditames do poder moral, à medida em que se aperfeiçoam as técnicas de controle sobre as mentes. Razoável, por isso, é concentrar a análise do poder nas relações interindividuais ao poder moral.

Este poder moral, sublinhe-se, é necessariamente um poder interindividual. Só pode existir, por definição, nas relações entre seres humanos. Tal poder implica sempre dois sujeitos que são os pólos da relação: o ativo (que tem poder) e o passivo (que sofre o poder). $O$ poder não existe se falta um desses elementos; assim, ninguém tem poder quando ninguém se sujeita a esse poder.

$\hat{E}$ ao poder moral que se aplica o conhecido conceito de Max Weber. Para este, poder, em sentido geral, significa «a possibilidade de impor a própria vontade sobre a conduta alheia» (6).

Este conceito, entretanto, precisa ser burilado. O verbo «impor» é forte demais para bem exprimir a variedade e a sutileza de muitas formas de poder. Este nem sempre é tão intenso que impõe uma conduta, não raro a influência apenas. O poder apresenta diversos graus de intensidade, todavia, nem é necessário dizê-lo, em todos eles obviamente existe poder.

Parece preferivel, por isso, dizer que o poder consiste na possibilidade de determinar pela própria vontade a conduta alheia. Determinação essa que se manifesta em graus variados que sempre importam, porém, no fato de que o sujeito passivo tem sua conduta estabelecida segundo normas que vêm de fora. De modo heterônomo, portanto. Pelo menos numa certa medida.

\section{A fonte do poder: a superioridade.}

Quem exerce poder pretende ter uma superioridade, ou pelo menos estar numa posição de superioridade, relativamente àquele cuja conduta quer orientar.

6. V. Economia y Sociedad, trad. esp., Mexico: Fundo de Cultura, $2^{\natural}$ ed., 1964, vol. II, pág. 696. 
Isto é patente quando o poder deriva da maior força. $O$ mais forte impõe porque sabe que, se preciso for, constrangerá fisicamente o mais fraco a proceder segundo a sua vontade. O mais fraco obedece porque tem conhecimento de que não poderá enfrentar com o êxito o mais forte. A superioridade de força, física, é a fonte de tal poder.

$\mathrm{Na}$ verdade, nem sempre essa superioridade é real - repita-se. O sujeito ativo pode supor que é mais forte e assim exercer poder. E o exercerá até que lhe seja contestada esta maior força, quando, aí sim, se ela não existir, estará findo o seu poder. Tal superioridade suposta não raro é fruto da voluntas dominandi que impulsiona os powerseekers ${ }^{(7)}$.

A superioridade da força não é, contudo, a principal fonte de poder nas sociedades contemporâneas. Muitas outras com ela concorrem: a de riqueza, a de sabedoria, a de inteligência, a do carisma, etc. E também a de status, tomando-se este termo tanto na acepção de posição social quanto na de situação numa hierarquia institucionalizada, como a da Igreja, ou a do Estado. Superioridades há que, importantes no passado, hoje se desvalorizaram, como a de nascimento, enquanto algumas se depreciam nos dias que correm: a de sexo e, talvez, a de raça.

\section{A fonte da sujeição: a crença.}

Como, todavia, uma superioridade suposta pode gerar poder?

A resposta não é vista, salvo se se encarar a questão não mais do ângulo do sujeito ativo e sim do ângulo do sujeito passivo do poder.

Com efeito, quem pauta a própria conduta pela vontade alheia, exceto na hipótese de constrangimento físico efetivo, o faz porque, consciente ou inconscientemente, aceita a superioridade do outro. Crê na superioridade de quem sobre ele exerce o poder.

No caso grosseiro da superioridade baseada na maior força, tal crença é a de não poder resistir se a compulsão for exercida, ou o temor de sofrer um castigo, uma sanção caso não obedeça. Em outros casos, o sujeito passivo do poder obedece porque crê dever obediência. A sua conduta, portanto, um dever-ser que está inscrito no seu patrimônio moral. Ele obedece porque crê ser direito que obedeça. E, sem dúvida como é humano, porque não quer sofrer a sanção associada à violação do dever-ser.

Todo indivíduo, e não apenas os que patologicamente são dominados pela voluntas subjectionis, tem gravada no espírito uma idéia do que é certo e do que é errado, portanto, de a quem é certo que obedeça. E sabe o que arrosta se desobedecer. Tal idéia é instilada

7. V. Robert A. Dahl, Modern Political Analysis, New Jersey: Prentice-Hall, 3 ed.; 1963, pág. 100 e segs. 
pela formação que, na família e fora dela, o indivíduo recebe, e, por isso, é variadamente amoldada. Entretanto, ela corresponde a um instinto inscrito certamente no próprio patrimônio genético do animal homem ${ }^{(8)}$.

\section{Modalidade de poder.}

Transparece do exposto que o poder moral apresenta diferentes modalidades. Estas podem ser encaradas, do ângulo do sujeito ativo, como graus de intensidade do poder. Estes graus, todavia, correspondem, do ânguo do sujeito passivo, a diferentes sancões. Com efeito, sendo os homens o que são, o que exerce poder, ao exercê-lo leva em conta a sanção que pode impor em caso de desobediência, e, sobretudo, quem obedece sempre leva em conta, ao obedecer, a sanção que arrisca, sopesa o «mal» que lhe advém por obedecer em face do «mal» que lhe resultará por não obedecer.

Por isso, o grau máximo de intensidade do poder corresponde à sanção mais temida. Ora, de modo geral, o que o homem mais teme é sofrer, no espírito sim, mas principalmente na carne. Teme a «pena», no sentido original do termo, ou seja, o castigo corporal. Assim, mais intenso é o poder que pode acarretar uma pena. Quem pode aplicar pena, impõe a conduta a quem teme a sanção. À imposição, pois, corresponde a pena.

Grau menor de temor inspira a sanção meramente moral: a reprovação social, que é a sua forma mais nítida. É esta tipicamente a sanção que colhe os que desobedecem à «autoridade».

Esse temor, porém, é ainda nitidamente superior ao que inspira o desagrado, que é relativo à influência, forma menor de intensidade do poder.

Pode-se, destarte, falando-se de modo geral, pois a sensibilidade em relação a cada sanção varia de homem para homem, distinguir três níveis distintös de intensidade do poder a que correspondem três niveis também distintos de sanções, nas relações interindividuais:

1. O mais alto, o do comando sancionado pela pena;

2. O médio, o da autoridade sancionado pela reprovacão, que sempre abarca todos os indivíduos que, formando o grupo social em que vive o indivíduo, para ele «importam»;

3. O mínimo, o da influência sancionado pelo desagrado, que apenas afeta o sujeito ativo do poder.

\section{O poder nos grupos.}

O que se disse a respeito do poder nas relações interindividuais aplica-se obviamente ao que se passa no âmbito dos grupos. Com efeito, é preciso não esquecer que estes não têm existência transcendente aos indivíduos que os compõem. Falar deles, pois, personali-

8. Cf. Edward O. Wilson, Da Natureza Humana, trad. port., S. Paulo, Queiroz, 1981. 
zando-lhes a existência, é útil figura de linguagem mas não passa de metáfora. O grupo é sempre um composto de indivíduos, embora para existir grupo seja necessário que esses individuos estejam integrados num feixe particular de relações. Relações interindividuais centradas num ponto comum - um centro de interesse - é que constituem o grupo.

Claro está que os caracteres de que se revestem essas relações interindividuais enfeixadas em grupo, variam e é em função dessa variação que se distinguem espécies de grupos. Por exemplo, e especialmente, a distinção entre massa, comunidade e comunhão, bem marcada por Gurvitch, levando em conta o grau de integração que tais relações realizam entre os indivíduos: uma fusão, no caso da comunhão, uma vinculação duradoura, no da comunidade, um liame efêmero e passageiro, no da massa ${ }^{(9)}$.

Por outro lado, no âmbito de grupo, a superioridade da força só é relevante em relação a agregados transitórios. Nos grupos estáveis, se a força pode gerar o poder, este não perdura pela força. O fato da maior força acaba por transformar-se, singelamente numa tradição, complexamente numa idéia justificadora, de tal sorte que a superioridade, e sua recíproca a sujeição, passam nela arrimar-se. Gera-se, pois, um poder tradicional, mantido pela lealdade.

\section{B. O poder nas relações entre grupos. \\ 9. O poder dos grupos.}

$\mathrm{Na}$ sociedade (global) ${ }^{(19)}$, os grupos exercem poder entre si. Existem relações de poder de grupo a grupo que são particularmente importantes e podem, até, ser vistas como o cerne da história. Com efeito, esta é, em última análise, a tese marxista da luta de classes.

Isto não quer dizer inexistirem nesse plano manifestações individuais de poder que sejam relevantes. E caso do poder carismático. Entretanto, é ele excepcional. Pelo menos na sociedade moderna, onde os indivíduos que exercem poder o fazem, de regra, integrados em. grupos, apoiados por grupos (como os partidos).

Inquestionavelmente, por isso, pode-se dizer que grupos determinam a conduta de outros grupos, exercendo sobre estes influência, autoridade ou comando. Exercem este poder imbuídos de que o podem fazer, ou de que têm o direito de fazê-lo, sobre grupos que aceitam esse poder, de bom ou de mau grado.

\section{A superioridade.}

A fonte do poder de um grupo não difere substancialmente das fontes de poder individual. Muitas são as razões de superioridade

9. V. Georges Gurvitch, Sociologia Juridica, trad, port., Rio de Janeiro: Kosmos, 1946, pág. 238 e segs.

10. Id., Traité de Sociologie, Paris: P.U.F., 1960, Tomo I, pág. 216 e segs. 
que, explícita ou implicitamente, invocam os grupos como base de seu poder: religiosas, econômicas, etc.

Não se pode menosprezar entre essas fontes a força. Esta, inclusive, é vista por não poucos como a determinante da distinção fundamental - a de governantes e governados - na sociedade global (11). Inegavelmente, contudo, a força não é, quando encarado na longa duração o poder de um grupo, a fonte determinante. Ela tende, sempre, a transmudar-se numa idéia justificadora do poder do grupo: superioridade de raça, desígnio divino, imperativo da providência, etc., como já se apontou.

$\mathrm{Na}$ verdade, o fenômeno de poder entre grupos é fundamentalmente um fenômeno de crenças.

\section{A sujeição.}

Com efeito, os grupos se sujeitam a outros, e todos ao grupo político, o dominante na sociedade num dado momento, ou em razão da experiência (o mais freqüente) ou em razão de uma justificativa racionalizada. Mas essa experiência, que perdura como tradição, e essa justificação, sempre, integram-se numa idéia de direito, parte da cosmovisão preponderante, a qual legitima o poder ${ }^{(12)}$.

\section{2. $\mathrm{O}$ poder e as crencas.}

Em qualquer grupo, reitere-se, o poder está relacionado a crenças. Isto é particularmente visível na sociedade global. Nesta, o poder está na dependência de um grupo de crenças, mais ou menos racionalizado, mais ou menos consciente, que inspira a sujeição e justifica a superioridade. E, no que tange ao grupo globalmente dominante, o que governa, como a força não pode fazer durar o seu poder, é sempre uma idéia do direito que lhe serve de fundamento do poder, posta de lado uma fase transitória em que talvez baste a força bruta.

De fato, em toda sociedade prevalece, tosca ou elaborada, uma concepção de justiça nas relações entre homens, entre indivíduos e grupos, entre grupos. Esta é uma idéia de justiça, porque define o que é justo naquela e para aquela sociedade. É idéia de direito, porque dela decorre o que é direito naquela sociedade para cada indivíduo e para todos os grupos ${ }^{(13)}$.

As relações de poder se fundam nessa idéia de direito, nessa concepção de justiça. E também a relação de governo, que é a relação

11. Cf. Léon Duguit, Traité de Droit Constitucionnel, Paris: Boccard, $3^{\text {a }}$ ed., 1928, $2^{\circ}$ vol., pág. 2.

12. A expressão «fátia de direito» foi emprestada das licõos de Georges Burdeau (ob. cit.). Entretanto, neste texto a sua compreensão e a sua extensão não são exatamente as mesmas que têm no famoso Traité de Science Politique.

13. Aproxime-se o que aqui está do ensinamento de John Rawls (A Theory of Justice, Oxford: Oxford Univ. Press, 1980, pág. 5) sobre a concepcão de justiça que todo homem tem. 
de poder à qual todos os membros dessa sociedade estão obrigados a obedecer. E a obedecer comandos que se impõem sob pena.

Ressalvada a exceção do poder carismático, que não se funda numa crença genérica e sim na crença no dom, excepcional, do sujeito ativo.

Para alguns, esse corpo de idéias seria a ideologia. Consistiria num conjunto de convicções, erigido por uma classe como racionalização de sua dominação sobre outras (14). Entretanto, se as elites preponderam incontestavelmente na definição da idéia de justiça, esta nem é obra exclusiva delas, nem é necessariamente a racionalização de interesses de classe. Ao contrário, resulta essa idéia daquilo que têm em comum todas as classes e todos os grupos, do vínculo que os integra numa sociedade.

\section{Legitimidade e «consensus».}

A idéia de direito, portanto, define quem comanda e quem obedece. Isto em qualquer grupo, inclusive na sociedade global. E estabelece também, na medida em que se pormenoriza, como se comanda e quando se obedece. Fixa, pois, o justo, o direito no tocante ao poder.

Em conseqüência, o poder escorado nessa idéia é o poder justo, legítimo segundo se usa dizer. Legítimo exatamente porque corresponde ao que é reconhecido como direito pelo grupo.

Esta legitimidade (objetiva) se funda, portanto, no consensus. Ou seja, no entendimento que serve de base e de ponto de referência para a vida em comum, entendimento que constitui o aceitável para a maioria, entendimento que faz o consenso ${ }^{(15)}$.

$\mathrm{Na}$ verdade, o consensus, propriamente falando, só existe quando uma grande maioria partilha desse entendimento básico (que, em última análise, é pacto social, ou melhor, as suas cláusulas). Com efeito, sendo informal, e numa certa medida fluído, esse consensus não pode apoiar-se numa simples, e transitória, maioria aritmética. Tem de contar com uma aceitação global por parte do grupo.

É verdade que a existência de consensus não reclama a inexistência de dissidência e de dissidentes. Raras são as situações e os momentos em que estes não existem. A regra geral, nos grupos secundários, é exatamente a presença de indivíduos que não subscrevem o entendimento geral e que, em especial, fazem do direito outra idéia. Para estes, de seu ângulo subjetivo, há uma legitimidade correspondente à sua concepção de justiça e não coincide, e se choca, com a prevalecente, a legitimidade há pouco qualificada de objetiva.

14. Cf. neste sentido de inspiração marxista, a lição clássica de Karl Manheim, em Ideologia e Utopia (trad. port., Rio de Janeiro: Zaher, 1968, pág. 81 e segs.).

15. V.M. Duverger, ob. cit., pg. 8. 
O alastramento da dissidência, ou das dissidências, obviamente põe em risco o consensus. E, atingindo certo ponto, o quebra. Ocorre, então, a crise de consensus que repercute em crise de legitimidade. Em tais ocasióes, mais breves ou mais longas, fervilham os conflitos, propiciam-se as revoluções, abala-se o poder tradicionalmente arraigado.

Entretanto, como o pacto social é imprescindível para a vida em comum, um consensus sempre acaba por se estabelecer. Às vezes, é grosso modo o anterior. Quer dizer, as condições do pacto em dado momento contestado voltam a contar com a aceitação global. Noutras, é um novo pacto, substancialmente diferente, vem a se impor. É neste caso, diga-se, que em termos sociológicos se pode dizer que ocorreu uma revolucão.

O novo consensus freqüentemente se estabelece de modo natural, por meio de uma reacomodação evolutiva e como que insensível. Todavia, não faltam exemplos, e contemporâneos, de imposição desse consensus por uma ação direta, consciente, objetiva por parte de um poder. Tal sucede quando um poder ilegítimo na origem (porque não correspondente à idéia de direito prevalecente e apoiado na força bruta), infunde uma cosmovisão no meio em que se instala. Com efeito, não só as técnicas tradicionais de educação e formação mas também, hoje, as técnicas modernas de propaganda, de mobilização, podem levar o grupo a mudar sua idéia de direito e mais do que a sua concepção geral das condições de convivência. É nisto, aliás, que se esmeram os partidos totalitários.

Ora, com esse consensus criado igualmente se gera uma nova legitimidade. $O$ poder na origem ilegítimo se legitima numa processo estendido no tempo, em que não falta, nunca, a repressão.

\section{O poder na sociedade global.}

\section{A institucionalização do Poder.}

Em qualquer grupo o poder pode institucionalizar-se. Isto é, ser separado dos indivíduos que o exercem, segundo regras preestabelecidas que o atribuem a um titular abstrato. Entretanto, o fenômeno mais importante de institucionalização ocorre na sociedade global.

Sendo muitas as fontes de poder, na sociedade costuma haver uma pluralidade de poderes. Nas sociedades menos evoluídas, porém, as fontes de poder tendem a se concentrar nos mesmos indivíduos, no mesmo grupo social (16). Este acumula o poder religioso, o poder econômico, o poder militar, o poder político.

Este poder «concentrado» se ajusta à individualização. Encarna-se num homem, em alguns poucos homens individualizados, que o

16. Pondo-se de lado as sociedades arcaicas em que o poder é anônimo ou difuso. V. G. Burdeau, ob. cit., vol. I, n० 205. 
têm como seu, como «coisa» sua. E um poder personalizado que se impõe no contacto imediato, face a face. $E$ obviamente a idéia de direito que o legítima, o faz em relação a pessoa ou pessoas específicas. $\mathrm{E}$ o que historicamente se revela nos relatos de ter sido o poder conferido a um indivíduo ou a um grupo pouco numeroso de indivíduos por um deus, ou pelos deuses.

À medida porém que a sociedade evolui e se torna mais complexa, o poder tende a descentralizar-se. Tem-no ainda um grupo, contudo não mais um grupo composto de pessoas que dele fazem parte por um direito seu, e sim um conjunto de pessoas que possuem o poder porque desse grupo fazem parte, porque pertencem à casta, ou elite dominante. Ou pelo nascimento ou pela cooptação, que são os critérios comuns.

No momento em que o poder começa a «desindividualizar-se» ele principia a institucionalizar-se. Com efeito, a idéia de direito já reconhece a legitimidade ao grupo não ao indivíduo, o que importa em admitir que o poder permanece embora os homens passem.

A desindividualização do poder implica uma «legalização» do poder. Ela se opera por meio da definição de regras que, consideradas obrigatórias, estabelecem o critério de integração no grupo, portanto, de participação no poder.

A institucionalização se concretiza ao se consolidar a idéia de que o poder não é apanágio de um indivíduo como tal mas tem um suporte que transcende aos que o exercem. Um suporte impessoal, em geral simbolizado, estruturado em normas obrigatórias.

\section{O poder político.}

Como poder político se há de entender o que assume a gestão dos interesses gerais da sociedade. É político, portanto, no sentido etimológico do termo: i.é, concernente ao bem geral (pondo-se de lado a tese marxista de que é ele, sempre, instrumento de dominação de uma classe sobre outra ou outras, de modo que sua finalidade é, ao contrário, um interesse particular - o de classe - e nunca o de todos).

Questão interessante e controvertida é a que tange à superioridade que o origina. Ou seja, a resposta à indagação sobre a qual a fonte do poder político.

O testemunho do passado que a história registra, a experiência do presente que a observação identifica, desmentem as respostas simples, não matizadas. Esse poder nem sempre é de fonte econômica (como querem os marxistas), nem sempre é de raiz militar (portanto na superioridade da força), nem sempre provém de crenças religiosas. Com efeito, as lições invocadas mostram que existiram, e existem, poderes políticos derivados de superioridade econômica, de superioridade militar, de superioridade religiosa, como poderes que derivam desses três fundamentos principais combinados em proporção variada. E 
sem excluir que esse poder pode ter fonte no carisma, ou estritamente política como ocorre contemporaneamente quando são políticos que se impõe porque são melhores políticos.

A raiz da sujeição, contudo, é mais fácil de encontrar, genericamente falando. A obediência deriva da idéia que na sociedade prevalece a respeito da superioridade relevante para a determinação dos rumos gerais, quando não decorre de um fato de força que depois busca a legitimação. Mas qualquer que seja a sua fonte não perdura senão quando se justifica em crenças. Em última análise quando alcança o consensus do qual se reflete a legitimidade.

Pondo-se como condutor do todo em vista de interesses gerais, o poder político naturalmente se afirma superior aos demais poderes. Isto não quer dizer, todavia, que lhe seja próprio o absorver, ou tentar absorver, todos os demais poderes que secretam os grupos sociais. Não, ele pode contentar-se, pondo-se como o mais alto, com definir o bem comum e impor que todos cooperem na realização deste, segundo ele o vê. Não lhe é inerente a inclinação totalitária, que, contudo, não é infreqüente na história, no Oriente, de há muito, é, hoje, também no Ocidente.

O poder político, tal qual qualquer poder, nem sempre é institucionalizado. Entretanto, em toda sociedade é bem cedo impelido nesse sentido. Com efeito, logo que esta se torna relativamente complexa, é sensível a tendência a desvinculá-lo dos indivíduos, que vivem e morrem portanto, passam para «encarná-lo» nalgo permanente que transcende os mortais. $\mathrm{E}$ consoante regras que regularizem a sua devolução e também o seu proceder e seu alcance.

Quando estas regras se estabilizam, o poder se tradicionaliza. Este poder tradicional está às portas do poder institucionalizado. Representa o estágio de que precede esta impersonalização. Historicamente todavia, se nas próprias sociedades arcaicas se nota o nascer do processo de institucionalização, esta é um fenômeno relativamente moderno. Ao culminar, marca ele o aparecimento do Estado.

Na verdade, o homem investido do poder político quando este é institucionalizado, tem um poder que resulta dessa investidura, independentemente de qualquer outra fonte, seja militar, econômica ou outra qualquer. Tem a superioridade de deter o poder político. Esta superioridade pode, e o mais das vezes isto ocorre, coincidir com outra ou outras, mas ela já pesa por si só. E freqüentemente mais do que todas as outras. O poder político institucionalizado, assim, é fonte de poder.

\section{O Estado.}

A institucionalização (plena) do poder político marca o aparecimento do Estado ${ }^{(17)}$. Este vem a distinguir-se da sociedade, e dos

17. O termo «Estado» não 6 unívoco. Daí diferir, na opinião dos mestres, o momento em que surge o Estado. Adota-se aqui a lição de Burdeau (ob. cit., ne 211, 212). 
grupos que a compõem, como a organização do todo com vista ao interesse geral. E correlativamente ao Estado afirma-se o Poder (com a devida maiúscula) que é a sede abstrata do poder político, transcendente dos indivíduos que o exercem.

Tal poder se põe naturalmente como superior aos poderes sociais. Para reger o povo, isto é, os indivíduos e os grupos nos quais se integram, ele há de ser superior a estes, pelo menos por função. Com efeito, para dirigi-los é preciso que sua orientação se presuma superior às decisões individuais e grupais. Como, por outro lado, o Estado se afirma territoriamente, esse Poder se coloca como superior numa órbita espacial e em relação aos que vivem, ou atuam, nessa área.

Há indubitavelmente uma relação entre esta supremacia que invoca o Estado e um fenômeno de força ${ }^{(18)}$. O poder institucionalizado deve ser mais forte do que os poderes sociais, ao menos isolados, para que se possa impor sobre eles. Tem de ser, numa palavra, incontrastável. Entretanto, nunca se pode olvidar que essa superioridade se arrima numa idéia de direito que consagra a prevalência do interesse geral (ou ao menos do que assim se apresenta) sobre os interesses particulares.

Este Estado, cujo Poder é incontrastável no plano interno a suas lindes, não necessita ser, logicamente, independente de qualquer outro Poder. E historicamente, como elucida a Idade Média, nem sempre o foi, pois nessa época largamente se admitiu a sua subordinação ao Império, ou ao Paparo.

Entretanto, o Estado moderno, obra de grandes monarcas do Ocidente, se caracteriza por seu Poder soberano. Ou seja, por afirmar o seu Poder como o mais alto (soberano, de soberanus, superlativo de super: o mais alto). Não só superior aos indivíduos e poderes sociais existentes num determinado âmbito territorial mas também não sujeito a qualquer outro poder. Confira-se aqui a lição clássica de Bodin, nos Six livres de la République ${ }^{(19)}$. Nesta obra, que consagra e teoriza a obra dos mencionados monarcas, põe ele a soberania como espinha dorsal do Estado. E por soberania entende o mestre a qualidade de um poder que não tem superior, que se deter. mina a si próprio, que não sofre nem teme contraste, seja dos poderes que se situam no seu âmbito espacial (interno), seja de poderes a ele exteriores. Mas tudo isto tem um pressuposto fático: ele é suficientemente forte para se impor a todos os que a ele se contrapuserem no âmbito interno, para impedir que outro poder se imiscúa nesse âmbito territorial que ele se reserva.

\section{Poder estatal e Direito.}

A primeira marca da soberania, segundo assinalava há quatro séculos Jean Bodin, é positivar o direito: «donner et casser da loi» (20).

18. Cf. Duguit, ob. cit., \$ 19 .

19. Cf. Jean Bodin, ob. cit., Paris, 1853, Livro I, cap. 89.

20. Id., ibid. 
Bem longe estava ele, é certo, de supor que o príncipe pudesse criar de sua vontade a norma obrigatória. O dar a lei era determinar, segundo a justiça, qual o direito. Revelá-lo, pois, em face de princípios de justiça que, ao tempo, se consideravam transcendentes mas que, certamente, simplesmente espelham a idéia de direito que faz a sociedade num determinado momento de sua história.

O mestre da República tinha, como todos os seus contemporâneos, a experiência (hoje até certo ponto despercebida) da pluralidade das fontes de direito. Cada grupo, todos os seus membros. $\mathbf{E}$ cada grupo as impõe a seus membros pelos meios de que dispõe. $O$ poder estatal, como o mais alto dos poderes e o que se incumbe do interesse geral, positiva o direito, o mais das vezes acolhendo normas geradas por grupos de âmbito restrito. Tal positivação não é sempre uma criação e no passado o era muito pouco frequentemente. Consiste, porém, em associar ao imperativo contido na norma a coercibilidade. Ou seja, a possibilidade de sua imposição pela força do Estado, pela força incontrastável que é própria ao poder estatal.

E, numa certa medida, o Estado edita direito para realizar sua tarefa de condução para o bem comum. É verdade que, pelo menos até o século XIX, o fazia modestamente, assumindo a posição de declarar o justo que, como tal, preexistia à sua enunciação. Somente ao assumir a missão de instaurar o bem-estar é que, com as bênçãos do voluntarismo jurídico, ousou criar normas obrigatórias. E especialmente normas instrumentais, as «normas de impulsão», enquanto anteriormente se limitava à explicitação de «normas de arbitragem» (21).

\section{O poder estatal na sociedade contemporânea.}

18. O poder «legal».

$\mathrm{Na}$ sociedade contemporânea, pelo menos nas que são ditas mais evoluídas, o poder estatal se ajusta ao tipo que Max Weber denominou de «legal» (22). Ele se funda num estatuto, isto é, num corpo de normas, legisladas ou costumeiras, que definem a quem compete esse poder, como ele se exerce e até onde ele se estende. Em princípio, portanto, o indivíduo investido no poder é obedecido porque é direito que assim seja. Direito que pode ser apenas «legal» ou também «legítimo», neste último caso quando se amolda à idéia de direito ancorada no consensus.

Entretanto, é intermitente no mundo atual o fenômeno carismático. Com efeito, em muitos Estados, e não dos menos ricos ou desenvolvidos, o poder tm sido tomado por indivíduos que pretendem ter um «direito» ao poder em razão de um dom, ou iluminação, espe-

21. V. do Autor, Do Processo Legislativo, S. Paulo: Saraiva, 2a ed., 1984, passim.

22. Ob. cit., pag. 707 e segs. 
cial, os quais encontram seguidores e como que fascinam todo um povo. Assumem assim, o poder político que se desinstitucionaliza, que no líder carismático se personaliza ${ }^{(23)}$.

Tal fenômeno seria, hoje, impossível sem os modernos meios de comunicação de massa. De fato, o carisma, que em sociedades pouco evoluídas é com freqüência fonte de poder político, não tinha até o desenvolvimento desses meios instrumento para alcançar mais do que um círculo pequeno, circunscrito ao que pode atingir uma irradiação pessoal. Com o desenvolvimento da eletrônica, essa irradiação pode alcançar, como atinge, o grande número e gerar, de novo, o poder carismático. Isto se viu bem claramente na Alemanha dos anos 30 quando Hitler, por meio do rádio sobretudo, conseguiu galvanizar milhões de pessoas. $\mathrm{E}$, com o seu apoio, não só conquistar o poder mas torná-lo coisa sua, a ser usado como bem parecesse.

Forma atenuada de carisma, é a personalização do poder, que se registra em praticamente todos os Estados contemporâneos (24). Consiste este fenômeno numa revalorização da personalidade, os das personalidades, em detrimento das idéias, na disputa do poder político. É ela ensejada por esses meios de comunicação, particularmente pela televisão que, por assim dizer, coloca os indivíduos em contacto «físico» como o líder, aceitando-o antes pela imagem do que pelo raciocínio. Isto enseja a «venda» de líderes, ou candidatos, pelo «merchandising» político, nova especialidade de agências de propaganda. E aproxima a técnica de busca do poder da que no mundo do espetáculo alicerça o star system ${ }^{(25)}$

\section{A «classe» política.}

Esse poder legal é detido na sociedade contemporânea, por uma «classe» política ${ }^{(26)}$. Ou seja, por uma minoria que se propõe como objetivo deter e exercer o poder político, especializando-se e empenhando-se (quase integralmente) em desenvolver e exercitar os dotes necessários à sua obtenção. Entre esses dons está sempre a capacidade de articulação - o dom das combinações de que fala Pareto (27), pela qual se obtém a colaboração de outros, formando o grupo de apoio que, em sociedades compostas de milhares ou milhões de membros, é imprescindível para o êxito. E, na medida em que a disputa é aberta, o dom de seduzir as massas ${ }^{(28)}$.

23. Id., pág. 847 e segs.

24. V. Leo Hamon e outros, La personnalisation du pouvoir, Paris: P.U.F., 1964.

25. V. Roger-Gérard Scrwartzenberg, L'Etat-spectacle, Paris: Flammarion, 1977.

26. Cf. Gaetano Mosca, The Ruling Class, trad. ingl. Nova Iorque: McGraw-Hill, 3* ed., 1965, cap. $2 \%$.

27. Cf. Vilfredo Pareto, Traité de Sciologie Générale, Genebra: Droz., 3̊a ed., 1968, cap. XIII.

28. Observa Mosca (ob. cit., cap. 2\%, no 3) que os «membros da uma minoria dirigente têm algum atributo, real ou aparente, que é muito estimado ou muito influente na sociedade na qual vivem». Que atributo outro que esse dom de articulação e de sedução pesa mais na democracia contemporânea? 
Com efeito, dada a importância que a democracia tem na idéia de direito predominante nas sociedades contemporâneas, o poder é objeto de constante disputa. Ou de disputa aberta por meio de eleições periódicas em que é necessário conquistar o voto do grande número, ou de disputa fechada, no seio de um grupo - normalmente o partido - em que se impõem que logra melhores combinações. Em ambos os casos, todavia, a capacidade de manobra sobreleva, porque esta é pelo menos necessária para reunir o grupo de apoio.

Depreende-se disto que a classe política é basicamente composta pelas «raposas». Esta é que possui as qualidades que no mundo atual levam à conquista do poder político, de acordo com a idéia de direito generalizadamente aceita. E certo que, em muitos países, os «leões» ocupam esse poder, ou por períodos intermitentes em que se quebra a legalidade, ou por periodos mais duradouros que normalmente se alcançam na medida em que esses «leões» demonstram ou logram os dotes das «raposas».

Esta elite política tende a criar interesses comuns, a assumir posições de «classe». Tal verificação é uma das fontes de ojeriza que tinham os socialistas, no século passado, à atuação parlamentar, pois viam nos trabálhadores eleitos traidores em potencial da classe de origem. E o fenômeno se tornou mais pronunciado a partir do momento em que a política passou a exigir dedicação exclusiva e tempo integral, como sucede nas democracias (e semidemocracias) contemporâneas. Daí a denúncia da transformação do mandato em profissão, sinal do abastardamento e deturpação da representação, que formula Tadieu ${ }^{(29)}$.

\section{Classe política e elite econômica.}

A tese de que o poder estatal está nas mãos de uma elite política contraria o mito de que ela é, sempre, um reflexo da que detém o poder econômico.

Ninguém negará que os detentores deste poder econômico influem sobre o poder político. Quer dizer, exercem poder sobre o Estado e sobre os que detêm o poder estatal. Em sociedades evoluídas, contudo, e especialmente nas que já penetram na era industrial, tendem a ser naturalmente dispersas as fontes do poder ${ }^{(30)}$. Nelas, o poder econômico se apresenta separado do poder político.

Ademais, a existência de uma fonte política do poder institucionalizado já de per si leva a essa separação, conquanto a detenção do poder estatal sempre importe em poder econômico (e mormente hoje quando o Estado é «empresário»). Nas democracias, porém, onde o

29. V. Dominique Turpin, «Critiques de la représentation», em Lo régime représentatif est-il démocratique, em Pouvoies, Paris: P.U.F., ne 7, 1978, pág. 7e segs.

Um dos críticos da representação, R. Prioret, afirma que os parlamentares «sentem a necessidade de se juntar cotovelo contra cotovelo para fazer face ao inimigo comum; que é o eleitor» (pág. 10). 
poder é objeto de uma disputa aberta, realizada por meio de eleições livres, o dom político leva ao Poder, independentemente da riqueza. Não há dúvida que, nesses pleitos, o aporte de recursos financeiros para a propaganda é importante e pode até determinar a vitória. Entretanto, globalmente falando não é suficiente nem eficiente o bastante para ditar a atribuição do poder político a este ou àquele partido. Do contrário a eleição estaria sempre assegurada a quem mais dinheiro contasse para a campanha.

E exato igualmente que os grupos econômicos, por meio da pressão sobre os eleitos, obtêm freqüentemente vantagens. Tal não ocorre, porém, de modo inexorável, mesmo porque há interesses contraditórios entre os grupos econômicos que competem e assim numa certa medida se anulam. É verdade, contudo, que essa influência é sobremodo grande sobre o poder estatal, maior do que sobre a conquista deste por este ou aquele líder.

Por outro lado, o Estado contemporâneo, tanto como planejador e controlador da economia, mas especialmente como empresário, e não raro o maior, em setores-chave da economia: indústria pesada, produção de energia, comércio bancário e internacional, etc., detém ele próprio um forte poder econômico. Por isso, mesmo pondo de parte os comandos que edita como soberano, o poder político exerce poder sobre os grupos econômicos. Está nisto um ponto saliente da realidade contemporânea, que raramente é levado na devida conta.

A tese, portanto, do primado do poder econômico, se na época em que foi formulada tinha certa verossimilhança, visto que, por meio de técnicas como o sufrágio censitário, o poder econômico lograva deter o poder político, não pode ser aceita como uma verdade que transcende as épocas ${ }^{(31)}$. E ela é desmentida pela experiência histórica que mostra a tomada do poder por grupos comunistas (e os comunistas são, de acordo com o Manifesto, a vanguarda do proletariado), em Estados cujo incipiente desenvolvimento econômico não tinha criado classe operária. Mas essa conquista do poder político por marxistas onde as condições que Marx considerava necessárias para o proletariado tornar-se classe dominante inexistiam, confirma a tese de que o poder político se alcança independentemente de poder econômico.

É paradoxal que apenas nos Estados marxistas é que existe a identidade entre classe política e poder econômico. De fato, os detentores do poder político são os que detêm plenamente o poder econômico ${ }^{(32)}$. Nos Estados ditos capitalistas, se, graças ao intervencionismo, o detentor do poder político tem poder econômico ele não o monopoliza, como os possuidores de poder econômico não monopolizam o poder político.

31. V. Mosca, ob. cit., cap. cit., no 5.

32. Cf. Juan J. Linz, «Totalitarian and Authoritarian regimes» em Handbook of Polltica] Science, Reading: Addison-Wesley, 1975, vol. II, pág. 187 e segs. 


\section{Poder político e poder militar.}

Em todas as épocas, em todas as sociedades, os mais fortes, os mais preparados para empregar a força física, tiveram, como têm, poder sobre o grupo que dirige o todo. Em muitos períodos e em toda parte, esse poder, que se pode chamar de poder militar, deteve o poder político ${ }^{(33)}$. Hoje ainda vez por outra, e com freqüência nalguns Estados, o poder militar empalma o poder político.

Entretanto, as próprias condições da sociedade contemporânea impedem que, duradouramente, o poder militar enquanto tal, baseado na maior força, detenha o poder político. A idéia de direito não legitima essa apropriação e os meios coercitivos não bastam para conduzir permanentemente a multidão e especialmente o escalão que enquadra e orienta a máquina estatal e as atividades produtivas.

Por isso, o grupo militar mais influi sobre o poder político do que $o$ detém. E quando o detém procura sempre cobrir-se de tal modo que pareça «civil». Adota, então, as aparências de grupo político, ou pelo menos rende preito às formas de atribuição do poder que consagra a idéia de direito predominante no mundo moderno. Faz realizar eleições, conquanto estas não sejam livres, constitui ou abençoa partidos políticos, etc.

Por outro lado, não se pode esquecer que o poder político toda vez que conta com a obediência do poder militar, pode usá-lo em sua defesa e nos seus interesses. É o que se registra quando a força é utilizada na repressão aos oposicionistas e dissidentes de toda espécie.

\section{Poder político e poder espiritual.}

Em vista da dependência que tem o poder em relação às crenças, os indivíduos que atuam sobre estas, às vezes detém o poder político $\mathrm{e}$, o que mais freqüente, sobre ele influem ${ }^{(34)}$.

Esse poder espiritual, por muitos e muitos séculos, se confundiu com o poder religioso. Sendo a religião a fonte da cosmovisão e consequientemente da idéia de direito, os seus porta-vozes ou intérpretes se apenas em algumas sociedades menos evoluídas constituíram o poder político (poder sacerdotal, ou poder de monarcas-deuses, ou sumo-sacerdotes), em toda parte e em todos os tempos, inclusive na atualidade, influem no poder político. E a história registra, por exemplo na Idade Média, a luta entre o poder político temporal e o poder religioso, em disputa da supremacia.

Hoje, porém, o poder religioso perdeu muito de sua influência e prestígio, no Ocidente. No Oriente, especialmente no mundo maometano, como demonstra o exemplo iraniano, ele é ainda suficientemente

33. V. Mosca, ob. cit., cap. cit., no 4.

34. Id ibid., cap. VII. 
forte para tomar o poder político, ou pelo menos para influenciá-lo decisivamente.

Entretanto, o enfraquecimento relativo do poder religioso no Ocidente não significa em termos absolutos a perda de influência do poder espiritual. De fato, se a religião perdeu força, a ciência e seus sacerdotes, os intelectuais, bem como a imprensa (neste termo englobados os que fazem a comunicação de massa) exercem intenso e extenso poder.

$\mathrm{O}$ poder dos intelectuais na sociedade contemporânea provém, por um lado, do prestígio que o saber confere e de certa forma sempre conferiu. Hoje, talvez mais do que em qualquer outra época, os homens confiam nos que sabem, especialmente quando esse saber vem aureolado como científico. E a razão é simples. O extraordinário progresso das ciências físicas nos últimos dois séculos, habilmente aproveitado na tecnologia, trouxe inequívocos benefícios para a vida de todos. O que se reflete no prestígio do saber, visto como instrumento de melhoria das condições e da qualidade de vida. Entretanto, não se nota, em geral, que esse prestígio não é merecido, em termos gerais, pelos especialistas de ciências humanas, pois estas avançaram bem menos. E não se toma a cautela de distinguir entre o campo em que o intelectual merece ser considerado especialista - e assim ser ouvido como quem sabe - e todos os outros em que seus conhecimentos não vão além da áurea mediocridade (quando chegam lá). Afinal, não há por que supor que um físico nuclear conheça algo mais de Ciência Política do que um indivíduo de razoável preparo escolar.

Por outro lado, é preciso sublinhar certas peculiaridades que marcam o intelectual contemporâneo, no mundo dito ocidental. Com muita razão, embora com uma pitada de sarcasmo (e quiçá de exagero), Schumpeter, em páginas memoráveis, fez a sociologia deste intelectual.Vale a pena reproduzir o cerne: «Os intelectuais são efetivamente gente que maneja o verbo, escrito ou falado, e que se diferencia dos outros escritores ou oradores pelo fato de que não assumem eles qualquer responsabilidade direta no que concerne às questões práticas: o intelectual, em geral, não possui qualquer dos conhecimentos que só fornece a experiência. Uma terceira característica consiste na atitude crítica do intelectual, determinada por um lado por sua posição de observador - e, por isso mesmo, na maior parte dos casos, de leigo - e pelo fato de que sua melhor probabilidade de se impor deriva das dificuldades que suscita ou poderia suscitar ${ }^{(35)}$. Texto particularmente importante concerne às conseqüências da expansão imoderada do ensino superior: desemprego, condições de trabalho pouco satisfatórias, etc., que azedam os intelectuais produzidos em massa.

$\mathrm{Na}$ mesma posição dos intelectuais em geral, porém. com maior potencial de influência, estão os profissionais da comunicação. Até

35. V. Joseph Schumpeter, Capitalisme, Socialisme et Démocratie, trad. fr., Paris: Payot, 1954, pág. 246 e segs. 
há pouco estes punham como missão informar. Claro está que esta informação que ministravam era sempre influenciada pelo parti pris inconsciente do informador, entretanto, o valor que conscientemente este se propunha era a verdade. Mais recentemente, porém, o comunicador assumiu a postura típica do intelectual. Ele «sabe» e porque sabe quer ditar, e sem dúvida influencia, a conduta de todos que recebem o seu «recardo» embora disfarçado de informação.

Não se exagere, contudo, o peso dos intelectuais, aqui incluídos os comunicadores. O povo, embora neles confie, não os segue como carneiros. $E$ isto bem se vê num período em que a esmagadora maioria desses intelectuais é «de esquerda» e mais ou menos marxista, mas os povos que podem livremente escolher os detentores do poder político freqüentemente se governam «à direita».

\section{A disputa pelo poder.}

Nas sociedades globais contemporâneos ocorre no seio da «classe» política uma disputa pelo poder. No seio da «classe» política, insista-se, não entre classes, como quer o marxismo. Com efeito, os indivíduos que pleiteiam o poder estatal somente metaforicamente podem ser apresentados como representantes das classes sociais. E a simbolização de classe que muitas vezes invocam não passa de «fórmula política», no sentido que Mosca dá a esta expressão, a justificar as suas ambições ${ }^{(36)}$..

São sempre indivíduos que disputam o poder. As classes sociais não existem como tais - será preciso lembrá-lo? - são grupos de indivíduos. Compõem-nas, portanto, indivíduos que apresentam certos traços comuns. Todavia, estes mesmos indivíduos diferem por uma infinidade de outros traços, inclusive, e especialmente, no tocante ao dom político, ou se se preferir no tocante à liderança. Estes indivíduos, dotados para a política, é que se dispõem a disputar o poder, com outros indivíduos, pertencentes por alguns caracteres a outras classes sociais, mas que com eles partilham o dom político.

$\hat{E}$ verdade que a competição não obedece à regra da igualdade das oportunidades. Os que são descendentes imediatos de outros que detêm ou detiveram o poder, ou que contaram com melhores condicões para adquirirem o preparo adequado, ou que têm maiores meios de influência pelo acesso aos meios de comunicação, partem com vantagem. Entretanto, no mundo de hoje, pelo menos nas sociedades modernas, não há castas fechadas que detêm com exclusividade o poder e o acesso a ele. Há sempre uma circulação que permite aos nascidos nos estratos mais pobres da sociedade, com grande esforço, não há dúvida, a ascenderem à elite do poder. E o grau mais elevado dessa circulação é indubitavelmente um dos traços caracterizadores de uma sociedade democrática. E obviamente esta circulação leva, 
aos poucos pelo menos, os descendentes da «classe» política que não contam com o respectivo dom a perderem o seu lugar entre os que detêm o poder. Mormente, porque a seleção eleitoral, que atribui o Poder de baixo para cima, a favorece ${ }^{(37)}$.

Estes indivíduos que, possuindo o dom político que valoriza cada tipo de sociedade, disputam o poder, por isso podem provir de diferentes classes sociais. E não é pela sua vinculação a esta ou àquela classe que se elevam a essa disputa, ainda que para os integrantes de certas classes, seja mais fácil fazê-lo. E desta regra não escapam as sociedades dominadas pelo comunismo, cujos líderes primeiros, salvo exceção, sempre provieram da burguesia. E que, em nome da dominação proletária, tentam fechar o acesso ao círculo mais alto aos que não provêem do proletariado, o que significa em geral os que não se vinculam à minoria dos ativistas do marxismo, à «nova classe» ${ }^{(38)}$. Mesmo nestas há a circulação, conquanto seja ela muito embaraçada pelos privilégios de que gozam os membros da «nomenklatura». Embaraço muito maior do que o que colhe os «proletários» em sociedades capitalistas, como os Estados Unidos.

Tal disputa pelo poder é um dos pontos fundamentais da ordem política dita «democrática» em voga no «Ocidente» o contemporâneo. De fato, é conceito arraigado o de que ninguém nasce com direito ao poder, que todos os homens são livres e destarte podem almejar as mais altas posições.

Este credo igualitário, todavia, não assegura que a competição seja realmente aberta, em toda parte. Ela existe em toda parte, ou quase, e segue em toda parte, ou quase, o mesmo ritual. Ou seja, a realização de eleições, das quais direta ou indiretamente resulta o governo, quer dizer, a posse do poder estatal.

Estas eleições, porém, nem sempre são significativas. Nem sempre nelas está verdadeiramente em disputa o poder estatal entre os indivíduos que pertencem à «classe» política.

Em realidade, em poucos Estados, essas eleições atribuem o poder, depois de uma disputa em que uma pluralidade de grupos têm a possibilidade de vencer. É $\mathrm{E}$ que ocorre nos regimes que merecem ser ditos democráticos, sem restrição mental. Noutros, mais nemorosos, a eleição, livre ou condicionada, enseja a disputa entre alguns grupos apenas, ou a certos indivíduos dentro de determinado grupo. Isto é típico dos regimes autoritários. Enfim, nos Estados totalitários, a disputa não depende dos resultados eleitorais que nela não influem. Nestes, as eleições são um rito, espécie de homenagem que o vício presta à virtude, servindo, sobretudo, à mobilização social (39).

37. Será preciso lembrar que o sistema eleitoral estimula a circulação? V. para a relação entre os sistemas de seleção de governantes, que chama de princípios, e a circulação, maior ou menor, entre elite e massa, que chama de tendências, Gaetano Mosca, ob. cit., cap. XV, ne 1 .

38. Cf. Milovan Dịilas, A nova classe, trad. port., Rio de Janeiro: Agir, 1958.

39. V. Linz, art. cit., pág. 210. 
Em face disto, a disputa em casos pouco nemorosos é aberta. $\mathrm{Na}$ maior parte deles é semi-aberta. E nalguns é fechada. Mas sempre existe. Mudam-se os métodos e as técnicas contudo ocorre a disputa mesmo nos Estados totalitários, só que nestes a disputa é restrita aos membros de uma cúpula e não depende de votações formais e sim de intrigas e manobras, ou barganhas.

\section{Poder estatal limitado e poder estatal totalitário.}

O poder estatal, como poder político, se volta para os interesses gerais do grupo social que é o povo. Importa sempre, portanto, embora o mais das vezes implicitamente, a definição do campo desses interesses gerais, a definição do que é «público», por oposição ao que é «privado» e assim há de ficar fora de seu alcance.

O pensamento político liberal acentuou sobremodo este aspecto. $\mathrm{E}$ dele resulta uma nítida separação entre o público e o privado. O domínio do privado é o dos direitos naturais do homem, que as Declarações, mormente a de 1789 , solenemente enunciaram. Tais direitos circunscrevem o terreno particular, em que cada um há de determinar a própria vida sem interferência de quem quer que seja, e especialmente do poder estatal. É o campo da liberdade individual, da «liberdade dos modernos» para recordar a famosa lição de Constante (ti). Em consequiência, só é lícito ao poder estatal atuar fora desse domínio privado. E, na verdade, para os liberais o domínio público é bastante restrito: consiste em assegurar a ordem. Função, pois, de polícia, do gendarme francês. Ế o Etat-gendarme.

As idéias «sociais» que, já no século XIX, se levantaram contra o liberalismo, seja entre os chamados socialistas, seja entre os «cristão-sociais» inspirados pela doutrina papal, incluem no campo público questões de ordem econômica, ou relativas à família e à educação, que eram estritamente privadas para os liberais. Entretanto, exceto alguns raros entre os socialistas (e esta referência se dirige a utopistas como Fourier e seu falanstério), ainda essa corrente demarcava bem nitidamente o público e o privado. E tal qual a liberal recusava a intromissão do Estado no domínio privado.

Somente no século XX é que encontrou defesa, seguimento, e mais que isso realização, a concepção totalitária. Ou seja, a de que o poder estatál há de reger tudo, o que elimina a separação entre o círculo público e o círculo privado. A formulação clara dessa idéia se deve a Mussolini: «Tudo no Estado, nada fora do Estado, nada contra o Estado» (41). A realização concreta desse programa, todavia, foi muito mais avançada pelo nazismo na Alemanha e pelo stalinismo na URSS. E nesta é que se encontra o mais perfeito exemplo de poder

40. Cr. Benjamin Constant, De l'esprit de conqề et de l'usurpation, $3^{\natural}$ ed., Paris, 1814, pág. 101 e segs.

41. A fórmula é do discurso de 28 de outubro de 1926. A tese está exposta no verbete «fascismo», na Enciclopédia Traccani. 
totalitário. Nela, é completo, total, o comando do Estado sobre a vida, toda, inteira, do indivíduo ${ }^{(42)}$.

\section{E. $O$ controle do poder.}

\section{Poder e abuso do poder.}

Onde se faz opção pelo poder não-totalitário, isto é, no chamado Ocidente, coloca-se o problema fundamental do controle do Poder e dos poderes, mormente do econômico, para a preservação da liberdade individual. Sim, porque o poder limitado no âmbito, embora, tem de ser controlado, pois do contrário se tornará opressivo. Como está no Espírito das Leis, «é uma experiência eterna que todo homem que tem poder é levado a dele abusar; vai até que encontre limites»(43)

A idéia de direito prevalecente na sociedade fixa o campo em que é legítimo o exercício do poder, de cada poder e mormente do poder político. Traça, pois, os limites dentro dos quais o poder atua do modo legítimo. Entretanto, não é raro, ao invés é muito freqüente, que o Poder, que os poderes ultrapassem esses limites. Incidam, portanto, em abuso.

Todo e qualquer poder pode tornar-se abusivo mas, sem dúvida, é o abuso de poder político, e hoje também o do poder econômico, que mais temem os homens. E não é por outra razão que o controle do poder constitui um dos temas capitais da Filosofia, da Ciência e do Direito políticos.

Do ângulo dos que sofrem poder, e são todos, e especialmente dos que sofrem o poder econômico e o poder político, e são quase todos, é compreensível que se almeje controlar o poder.

O primeiro passo para tanto é fixar os limites que o poder não pode ultrapassar. Estritamente falando, limitar o poder. $\mathrm{E}$ isto significa estabelecer uma fronteira bem definida, por meio de normas claras que eliminem as zonas cinzentas e traduzam sem deixar dúvida o que se esboça na idéia de direito.

Isto é insuficiente, porém, segundo mostra a lição dos tempos. O poder apenas respeita esses limites se outro poder o detém, ou freia. Limites desprotegidos, limites não garantidos por outro, ou outros poderes, são inúteis, ou quase. 'É preciso - como ensina Montesquieu que «o poder detenha o poder» ${ }^{(4)}$. Poder, destarte, é imprescindível para conter o poder, no seu campo legítimo.

Todavia, quando o poder é o estatal, que se põe como o mais alto, como controlá-lo, A doutrina da auto-limitação que Jellinek propugnou é fraco e decepcionante consolo, que somente agrada a ju-

42. Ce. Linzs, art. ?cit.

43. Livro XI, cap. IV.

44. Id. ibid. 
ristas ${ }^{(45)}$. Dai a fórmula política da democracia, ou seja, assumirem os próprios governados o Poder, realizando a identificação máxima entre sujeitos e titulares do Poder.

\section{O controle do poder.}

Três, portanto, são os modos básicos pelos quais se controla o poder. E todos eles já se aplicam ao poder político ${ }^{(46)}$.

O primeiro é o controle por limitação. Consiste em definir o que o poder pode fazer, o que ele não pode fazer. É esta a tarefa do Direito que, por um lado, fixa competências, ou capacidades, por outro, define a linde entre o lícito e o ilícito. E tipicamente o Estado de Direito, em sentido estrito, apoiado na legalidade e na igualdade, sobretudo.

O segundo é o controle por contraste. Consiste em manter o poder num âmbito delimitado, em razão de um jogo ou sistema de forças. Presume, portanto, que poderes se anteponham a um poder, e mormente ao Poder, impedindo-o de ir além da fronteira estabelecida pelo Direito. Gera o sistema de «freios e contrapesos» em que tanto confiavam os liberais. E o governo misto dos antigos, a separação de poderes dos modernos.

O terceiro é o controle por dominação. Consiste em ter o poder, e sobretudo o Poder, para não deixá-lo ir além dos limites fixados. Nisto está a contribuição fundamental de Rousseau para a democracia contemporânea, contribuição essa dada por meio da doutrina da vontade geral.

Mas, fechando-se o círculo, cabe repetir o registro do Espírito das Leis: «Quem o diria! A própria virtude tem necessidade de limites» (47). De fato, a democratização do poder, segundo a experiência, não dispensa a sua limitação, nem o seu contraste, se se quer, realmente, salvaguardar a liberdade individual. $O$ poder democrático também pode ser opressivo.

\section{Controle do Poder e Constituição.}

Preocupado com o controle do Poder, no qual via o inimigo por excelência da liberdade individual, o pensamento iluminista encareceu um instrumento jurídico - a Constituição - como meio de instaurá-lo. Entretanto não valorizou toda constituição, isto é, qualquer organização estatal, e sim aquela que garantisse os direitos fundamentais do Homem e estabelecesse a divisão funcional do poder segundo a fórmula de Montesquieu. Assim, somente teria verdadeiramente 1912.

45. V. Georg Jellinek, Sistema dei Diritti Pubblici Subbiettivi, trad. italiana, Milão,

46. V. sobre o controle em geral, Robert A. Dahl e Charles E. Lindblom, Politics, Economies and Welfare, Chicago: Un. Chicago, 29 ed., 1976, pág. 93 e segs.

47. ob. cit., loc. cit. 
uma Constituição o Estado em que, por escrito, estivesse «assegurada a garantia dos direitos e determinada a separação de poderes», consoante exige o art. 16 da Declaração dos Direitos do Homem e do Cidadão de 26 de agosto de 1789.

Em outros termos, a Constituição, segundo a concebiam os revolucionários liberais, não mereceria esse nome se não consagrasse o controle por limitação e o controle por contraste. O primeiro, decorrente do enunciado dos direitos naturais, feito pela Declaração e garantido na Constituição, o segundo, resultante da divisão do exercício do poder entre «poderes» independentes, para que cada «poder» servisse de freio e contrapeso para os demais. E, acrescente-se, limitação e contraste vistos como intimamente ligados.

O controle por dominação, embora o Contrato Social seja de 1762, foi adotado bem mais tarde, quando, a partir da França em 1848, se estabeleceu o sufrágio universal, ainda que apenas masculino. De fato, a linha principal do pensamento liberal era elitista. Montesquieu é claro ao registrar que os homens em geral não têm a capacidade de «discuter les affaires», ou seja, de colaborar para a «boa» solução dos problemas governamentais. Só lhes é dado escolher os «representantes» que hão de ser mais sábios que seus eleitores, aos quais não falta o discernimento e a experiência - é verdade — necessária para bem escolhê-los ${ }^{(48)}$. Daí o «governo representativo» que as Revoluções instauram, seguindo as fórmulas de Sieyès e imitando as instituições inglesas ${ }^{(49)}$.

Contudo esse governo representativo, que o autor do Qu'est-ce que le Tiers Etat? cuidadosamente distinguiu do governo democrático, não resistiu à lógica da igualdade. Com efeito, era incoerente reconhecer a igualdade de direitos entre todos os homens e recusar a participação política, plena, à maioria como resultava do sufrágio censitário. A coerência levou ao sufrágio universal, o governo representativo evoluiu para a democracia representativa.

A extensão do voto às camadas mais pobres não teve os resultados políticos imediatos que ao tempo se esperavam. Não instaurou, de pronto pelo menos, o socialismo, barrado o caminho pelos direitos individuais consagrados - entre os quais a propriedade. Nem levou ao governo da plebe, que tanto temia um Sieyès, em virtude do fenômeno social já descrito de que o poder sempre fica das mãos de uma minoria, de uma elite. Elite, até, que tende a se por como «classe».

Esse fato, porém, conduziu a uma mudança na maneira de conhecer a missão do Estado. Com efeito, o peso político dos mais pobres e sua pressão levou ao abandono do laisser faire, portanto ao Estado

48. Ob. cit., livro XI, cap. VI.

49. Sieyès propugnava o governo representativo e se opunha ao governo democrático, que, a seu ver, seria dominado pela plebe e pela demagogia. V. suas observations sur lo rapport du comité de constitutíon, Cf. Paul Bastid, Sieyès et sa pensée, Paris: Hachette, 2 a ed., 1970, pág. 369 e segs. 
intervencionista, ao Estado-providência. E com este inúmeras conseqüências, quer no relacionamento entre os «poderes», quer na separação entre o «público» e o «privado», como a de introduzir na Constituição, antes mero controle do Poder, toda uma programação a ser realizada por este Poder. Passa tal Poder, de «inimigo» para a posição de «amigo» do povo.

Hoje, há inegável decepção com o Constitucionalismo. Este não estabeleceu o reino da liberdade que dele se esperava. A adoção de Constituição, a promulgação de documento solene em que se limita o poder, se divide o poder, se atribui ao povo o poder, não bastou para garantir a liberdade ou instituir a democracia em toda parte. A edição de constituição escrita se tornou um rito, que a modernidade não dispensa. Entretanto, muitas são as condições, raramente satisfeitas, para que a Constituição seja efetivamente respeitada, e, portanto, controlado o Poder.

Para que haja limitação ao Poder, é preciso que o Direito consagre o que o consensus considera justo. Ora, quando há quebra de consensus, fenômeno tão freqüente e tão espalhado no mundo atual, o direito é o que o Poder quer e pode impor. Para que haja contraste ao Poder, é mister que esteja vivo na sociedade o pluralismo e dispersas as fontes de poder. Ora, o Poder, em face de uma sociedade acomodada, sabe absorver os grupos, instaurado um monismo, pelo menos aproximativamente. E, para gerar o bem-estar, assumiu poder econômico que o torna onipresente. Para que haja dominação do Poder, é necessário que o povo se disponha a participar ativamente, constantemente, da condução dos negócios públicos. Ora, isto cria incômodos que o egoísmo e o imediatismo infundidos por uma formação individualista afugentam.

\section{Direito e controle do poder e pelo poder.}

O ideal de liberdade, tão valorizado no mundo contemporâneo (ao menos ostensiva e vocalmente), confiou no Direito para a sua instauração. Era a Constituição (jurídica) que devia encerrar o Poder sob controle, eram os direitos naturais do Homem que deviam limitá-lo. Mais, o Poder se devia estruturar em função da lei, em poderes dos quais um a declarar, outro a executar e um terceiro julga segundo ela, de tal forma que o Estado só poderia atuar pelo direito: o Estado de Direito.

Já se viu logo acima com que medida de êxito isto se logrou. O Estado contemporâneo é de «Direito», no sentido de que observa as formas jurídicas na sua atuação. Contudo, o direito é ele quem estabelece em substância, o mais das vezes. O direito não é posto como expressão do justo e sim como o resultado de um comando estatal, independentemente de seu conteúdo. E esse direito que o Estado edita náo raro contra a idéia de justiça prevalecente no grupo, nem sempre é observado por ele próprio. 
Tal Estado legal muito longe está do ideal do Estado de Direito, de que tomou as aparências, apenas. E esta deformação o permite ser muito mais opressivo do que o eram as tão criticadas monarquias de direito divino. Com efeito, ao tempo do Ancien Régime, não se admitia que o Estado criasse o direito. A sociedade é que espontaneamente o segregava, segundo, é claro, a idéia de justiça que nela existia. O monarca «absoluto» não podia abolir os direitos e nisso estava a sua fraqueza e nisso está a causa por que não pôde realizar as reformas que sua sobrevivência reclamava. Sem dúvida, o Estado liberal, ao pôr a lei como expressão da vontade geral, não pretendia que o legislador pudesse criar a lei, e sim apenas declará-la. Mas a fórmula permitiu o abuso: que o comando do legislador fizesse a lei.

Ora, na medida em que o legislador faz a lei, esta não mais é, fundamentalmente, limite do Poder. Torna-se instrumento do Poder ${ }^{(50)}$. Por meio desse direito, quer dizer, estabelecendo obrigações suscetíveis de imposição coativa, o Poder controla os governados.

O direito, atualmente, é menos controle do Poder do que instrumento de controle pelo Poder. Este controle pelo Poder enseja grandes transformações, como comprova a impulsão que por meio dele se dá ao desenvolvimento político, econômico e social. É ferramenta de mudança esse direito feito pelo legislador enquanto era arma de conservação (relativamente) o direito lenta e naturalmente segregado pela sociedade.

Mas esse direito que serve à impulsão em vista de determinados objetivos imediatos e concretos, é cambiante. Tem de mudar com a evolução das situações, e com a alteração dos objetivos a que disputa política conduz. $\mathrm{E}$ isto os desvaloriza. Visto como vantagem para certos grupos, como desvantagem por outros, já que é a maioria que o faz e desfaz, independentemente do consensus em torno de uma idéia de justiça, ele se desprestigia. E desvalorizado e desprestigiado perde força como instrumento de reforma e como instrumento de controle. A lei, ora a lei...

Não é por outra razão que contemporaneamente se encarecem outras técnicas de controle social. É o controle por manipulação que atua sobre as mentes, visando a induzir ou coibir atitudes, sem que seja necessário recorrer à lei e seu comando coercitivo.

Parece indubitável que, se se deseja manter, ou renovar, ou reforçar, o controle sobre o Poder, é preciso começar por restaurar o Direito. Este há de ser o justo, não o querido por um poderoso qualquer. Jus quia justum, non jus quia jussum.

E não se deve supor que controlar o Poder basta para garantir a liberdade. Outros poderes a ameaçam, como o tão mencionado poder econômico - inclusive o do Estado, que também tem de ser controlado.

50. Cf. do Autor, Do processo Legislativo, ob. cit., especialmente no 184 . 